\title{
Preliminary Observations on the Rock-Cuttings of Tell Sandahannah
}

\section{R. A. Stewart Macalister}

To cite this article: R. A. Stewart Macalister (1900) Preliminary Observations on the RockCuttings of Tell Sandahannah, Palestine Exploration Quarterly, 32:4, 338-341, DOI: 10.1179/ peq.1900.32.4.338

To link to this article: http://dx.doi.org/10.1179/peq.1900.32.4.338

册 Published online: 20 Nov 2013.

Submit your article to this journal \lceil

Џll Article views: 5

Q View related articles $\asymp$ 
had been robbed at some earlier period, unknown to us as well as to the natives themselves. From them we learned that only about 10 per cent. of the tombs opened by them were discovered intact; a fact which not only alleviated our disappointment, but explained the comparatively small number of objects which have found their way to the archæological market. . . . .

Amongst numerous articles found was a female figure in terra-cotta, of which photographs in two positions are sent. On the head is a bonnet or head-dress, under which the hair is gathered in a knot behind. From the shoulders depends a cloak, which leaves the upper part of the body bare and is held up in front by the left hand. The right haud clasps the left breast.

In the other unrified tomb are five hollow bench-graves, closed in by covers. In one case only these were cemented together. Within the graves were two gold earrings and two nails, one iron the other bronze. . . . . . . . . . . . Jerusalem, September 10th, 1900.

\section{PRELIMINARY OBSERVATIONS ON THE ROCK- CUTTINGS OF TELL SANDAHANNAH.}

By R. A. Stewali Macalister, M.A.

ON the contour plan ${ }^{1}$ accompanying Dr. Bliss's Report the plans of nearly all the artificial caves on Tell Sandahannah are laid down. There are a few which (having deep perpendicular entrance shafts that required a longer crane rope than we possessed) could not be entered: two or three others within the limits of the plan which were not measured for lack of time (so far as explored, these add nothing to our knowledge of the subject), and a few outside the limits of the plan (of these only two are of special interest, and they have been planned separately). As some 50 cuttings remain after these are excluded, it may reasonably be claimed that sufficient material for the study of the Tell Sandahannah caves has been collected.

1 Publication of this plan is deferred (see p. 319). 
Female figure is Terra-Cotta.

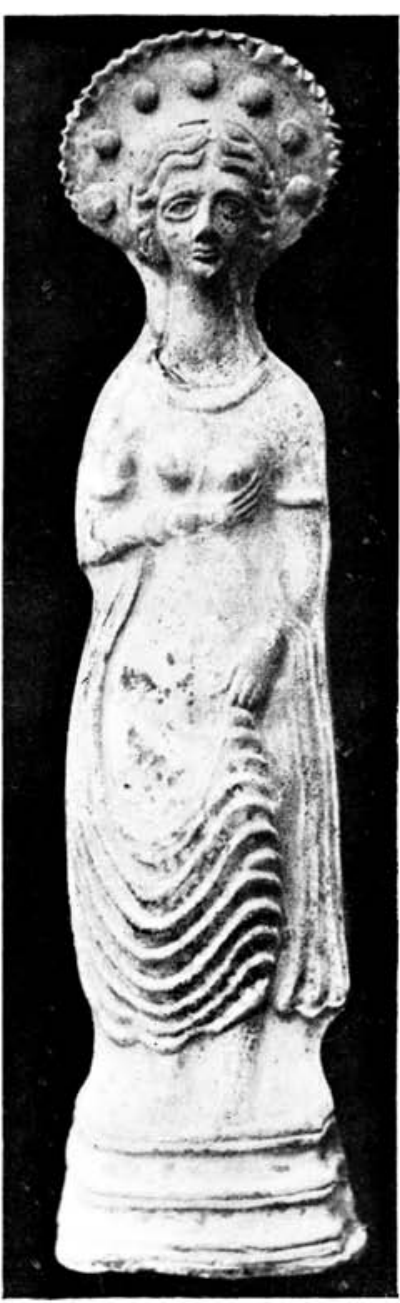

Front View.

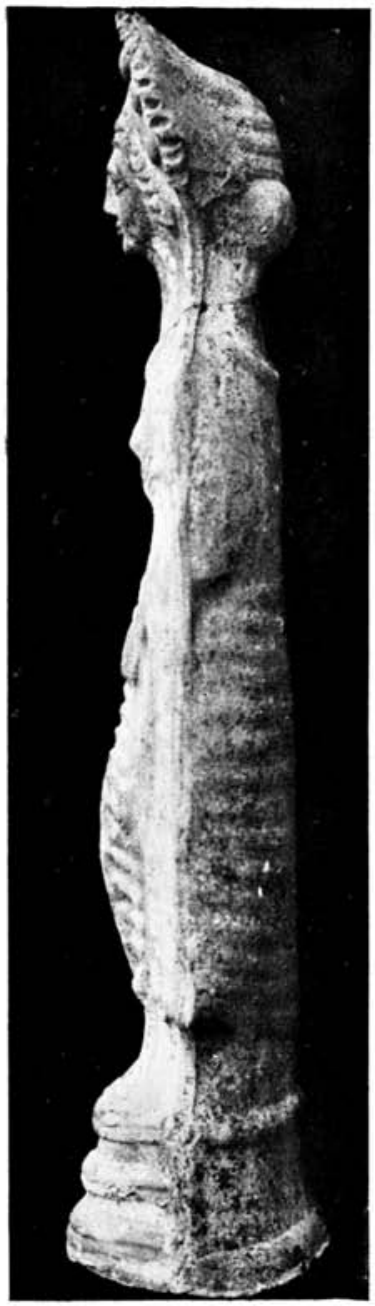

Side View. 
The caves in this group show several peculiorities of design. In nearly every case the bell-chambers are provided with parapets on the outside of the staircases. In systems of grouped chambers the various apartments communicate with each other as a general rule directly, not (as at Khurbet el-'Ain and Zakarîya) by passages. When passages do occur they ustally are sufficiently large to be traversed without stooping; there are only two or three "creep passages" in the whole series. Another important peculiarity consists in the incorporation of stepped bell-chambers with extended systems; these are absent from the groups of chambers I have examined elsewhere.

A distinctive and, in some respects, puzzling feature of the Sandahannah series is the large number of columbaria found even in remote parts of these excavations. There is only one circular columbarium on the Teli (outside the limits of the plan, to the north-west). On the other hand, there are many columbaria which on plan consist of groups of more or less rectangular passages: these are either independent excavations, as in a large example on the plan to the west, ${ }^{1}$ and another, outside the plan, south-west from it; or associated with other chambers, as in several of the great souterrains to the east and south-east. One columbarium is distinguished from all the rest by the care which has been bestowed upon it, both in design and workmanship. This is of course the well-known $S u k$; it calls for a more extended description than can be accorded to it in the present cursory remarks.

Besides the columbaria there are several examples of elaborate rock-cut oil presses, which are of considerable interest. These will be fully described later, with plans, \&c., of the finest example.

One chamber has every appearance of having been a rockcut stable, with stalls, tether-holes, \&c.

In the remaining chambers examined-considerably over 400 in number-there is a provoling absence of indication of their purpose. Some of the bell-shaped pits are undoubtedly

1 There are one or two chambers connected with this system not showing loculi, but they are insignifieant in comparison with the extent of the system. 
water stores, as is demonstrated by the existence of water channels leading to them, and by the marks of ropes on their sides caused by lauling up pitchers. There is one group of bell-chambers of considerable interest. The first is about. 20 feet deep, the second-a double chamber, 19 feet deep, with a staircase having two parapets running between the two apartments-is entered by a door which is at its top, and at the bottom of the first. In the middle of the floor of the second is a cylindrical shaft, 50 feet deep, and apparently about: 6 or 8 feet in diameter (it is narrower at the top). This gives a total depth of 90 feet for the excavation. The presence of rope marks at the mouth of the shaft demonstrates that it was a well, probably communicating with a now exhausted spring.

The rooms (other than bell-shaped pits) are either circular, quadrangular, or irregular apartments, supported, when necessary, by heavy square columns hewn out of the rock.

The number of wall inscriptions or graffiti is extremely small. They comprise :-(1) A Greek inscription in the columbarium known as Es-Sutk. (2) Three Hebrew letters, each on a. separate panel, and apparently not connected with one another, on the wall of a chamber in Mughâret Sandchannah; the date. seems to be between the third and first century B.c. (3) Crosses in one ceve only; this is significant. (4) A rude human figure. outside the entrance to a cave near Es-Sûk ; and (5) a figure resembling those in 'A.rîk el-Ma, generally interpreted as a rude representation of the Crucifixion, but by Père GermerDurand compared with the orantes with arms extended in the Calacombs. ${ }^{1}$

Another important peculiarity of the Sandahannah caves. is the frequent occurrence of masonry in association with them. In many cáses there are small square fuundations surrounding the mouths of caves, as though the latter formed the cellars of houses now almost destroyed. In others the masonry is an intrinsic part of the cave itself, and is found (a) lining a wall. (in Mngharet Sandahannah there are two complete chambers. so liued), (b) completing a portion which had erroneously been.

1 See the "Revue Biblique," July, 1900, p. 485. 


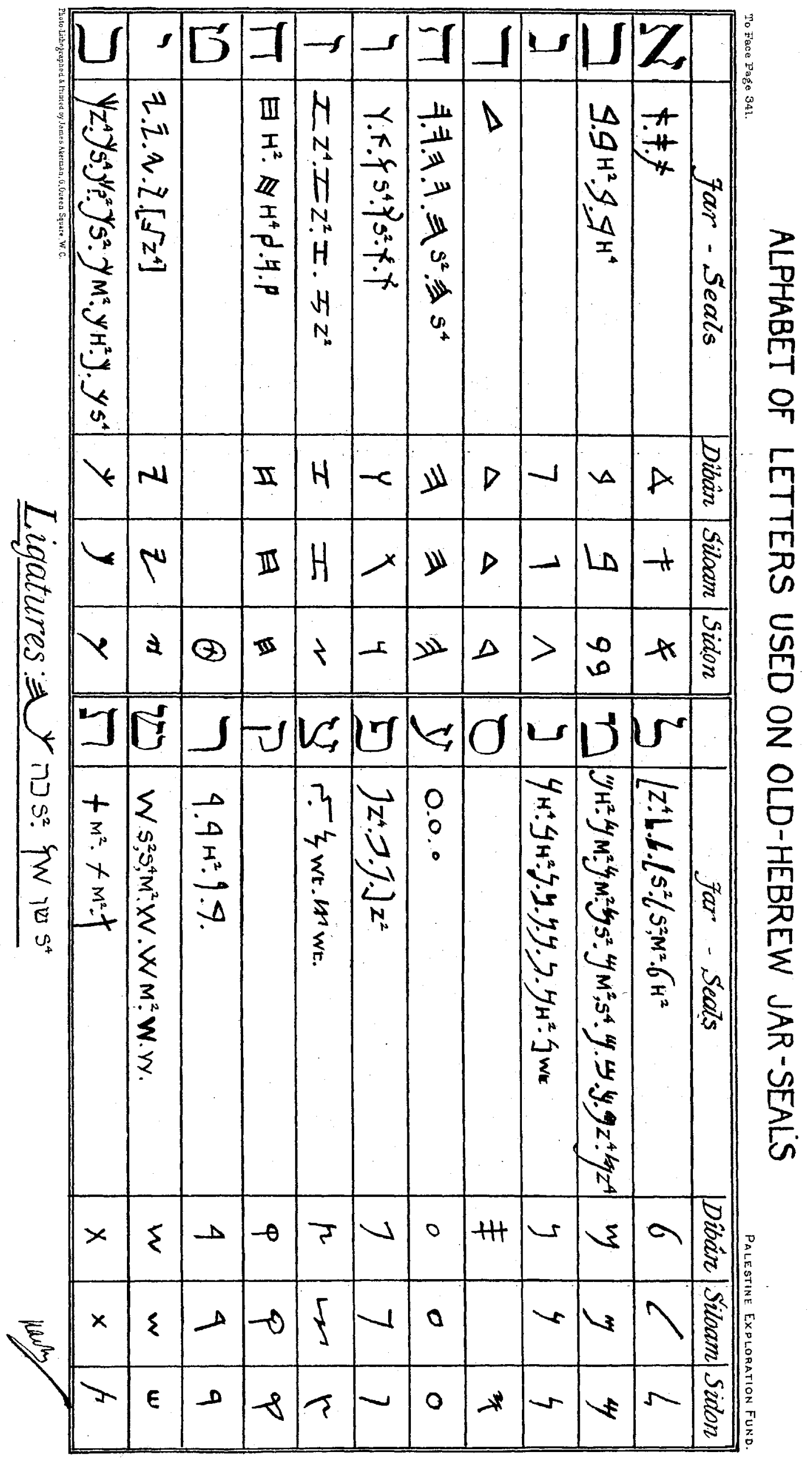


cut away (as in one of the olive presses, in which one upright staple has been replaced by masonry, the others all being rock), and $(c)$ vaulting over a chamber or passage near the top surface of the rock. In the majority of cases the vault is a barrel arch of narrow span (thore is one fine wide arch only) with regularly cut voussoirs. There is one false-arch dome in the series stopping up a temporary manhole. The masonry is all built. in brick-shaped blocks of howwar (clunch), and is always remarkably true and well finished.

\section{ALPHABET OF LETTERS USED ON OLD-HEBREW JAR SEALS.}

\section{By R. A. Stewart Macalister, M.A.}

TнE preparation of the accompanying plate, intended to illustrate the report printed in the July number of the Quarterly Statement, was nnavoidably delayed. All the varieties of the different letters are shown and compared with the characters of the three principal monuments engraved in the "Phoenician" alphabet. The reference letters denote the type of handle on which the letter was found, H, S, Z, M, stand for Hebron, Shocho, Ziph, and respectively; $\mathrm{H}^{2}$ and $\mathrm{H}^{4}$ denote "two-winged type" and "four-winged type" of "Hebron" seal : and so for the rest. The letters Wt. stand for "weight," indicating that the ebaracter appeared on one of the small dome-shaped stone weights found at Zakarîya and elsewhere. When no indication of source is given the stamp is one of those bearing the names of private owners. 